\title{
PENGGUNAAN ESTER SUKROSA UNTUK MEMPERBAIKI KARAKTERISTIK FISIK DAN ORGANOLEPTIK ES KRIM SAWO MENTEGA
}

\section{APPLICATION OF SUCROSE ESTER TO IMPROVE PHYSICAL AND ORGANOLEPTIC CHARACTERISTIC OF CANISTEL ICE CREAM}

\author{
Maulana Noor Fajri Al Hajar, Dwi Lestari Rahayu \\ Program Studi Pendidikan Teknologi Agroindustri, Universitas Pendidikan Indonesia \\ maulana_nfa@student.upi.edu
}

\begin{abstract}
ABSTRAK
Penggunaan ester sukrosa dapat memperbaiki karakteristik es krim tepung buah sawo mentega. Tujuan penelitian ini adalah untuk mengetahui penggunaan ester sukrosa terhadap karakteristik fisik dan organoleptik es krim tepung sawo mentega. Penelitian ini menggunakan Rancangan Acak Kelompok (RAK) faktorial dan dua kali ulangan. Faktor pertama adalah penambahan ester sukrosa dengan taraf $0,1 \%, 0,3 \%$, dan $0,5 \%$, faktor kedua adalah penambahan tepung sawo mentega dengan taraf $10 \%$ dan $15 \%$. Hasil penelitian menunjukkan bahwa penambahan ester sukrosa $0,1 \%, 0,3 \%$, dan $0,5 \%$ pada es krim dengan tepung buah sawo mentega $10 \%$ memiliki nilai overrun masing-masing sebesar $71,43 \%, 74,10 \%$, dan $93,57 \%$; pemisahan krim pada stabilitas emulsi sebesar $0,250 \mathrm{~cm}, 0,225 \mathrm{~cm}$, dan $0,175 \mathrm{~cm}$; waktu leleh selama 24,31 menit, 26,16 menit, dan 31,00 menit; viskositas sebesar $14680 \mathrm{cP}, 18620 \mathrm{cP}$, dan $12730 \mathrm{cP}$ serta total padatan terlarut sebesar 33,47\%, $33,62 \%$, dan $36,47 \%$. Penambahan ester sukrosa $0,1 \%, 0,3 \%$ dan $0,5 \%$ pada ek skrim dengan tepung buah sawo mentega $15 \%$ memiliki nilai overrun masing-masing sebesar $50,00 \%, 57,14 \%$, dan $64,28 \%$; pemisahan krim pada stabilitas emulsi sebesar $0,250 \mathrm{~cm}, 0,150 \mathrm{~cm}$, dan $0,150 \mathrm{~cm}$; waktu leleh selama 30,02 menit, 33,33 menit, dan 36,13 menit waktu leleh; viskositas sebesar 16560 cP, 17020 cP, dan $17380 \mathrm{cP}$ viskositas; serta total padatan terlarut sebesar $33,62 \%, 34,47 \%$, dan $39,98 \%$. Penambahan ester sukrosa pada es krim dengan tepung sawo mentega 10\% menghasilkan penerimaan hedonik antara biasa dan suka terhadap warna; suka terhadap tekstur dan rasa, serta biasa terhadap aroma. Penambahan ester sukrosa pada es krim dengan tepung sawo mentega $15 \%$ menghasilkan penerimaan hedonik antara suka hingga sangat suka terhadap warna, biasa terhadap tekstur dan rasa, serta antara biasa hingga suka terhadap aroma.
\end{abstract}

Kata kunci: es krim, sawo mentega, ester sukrosa

\begin{abstract}
The purpose of this study was to determine the use of sucrose esters on the physical and organoleptic characteristics of canistel flour ice cream. This study used factorial Randomized Block Design (RBD) with two replications. The first factor was addition of sucrose esters with concentration were $0.1 \%, 0.3 \%$, and $0.5 \%$. The second factor was addition of canistel flour with concentration were $10 \%$ and $15 \%$. The results shown that the addition of sucrose esters $0.1 \%, 0.3 \%$, and $0.5 \%$ on ice cream with $10 \%$ canistel flour had each overrun value were $71.43 \%, 74.10 \%$, and $93.57 \%$; cream separation value on emulsion stability were $0.250 \mathrm{~cm}, 0.225 \mathrm{~cm}$, and $0.175 \mathrm{~cm}$; melting point in 24.31 minutes, 26.16 minutes, and 31.00 minutes; viscocity in $14680 \mathrm{cP}, 18620$ $\mathrm{CP}$ and $12730 \mathrm{cP}$; and total dissolved solids value were $33.47 \%, 33.62 \%$, and $36.47 \%$. Addition of sucrose esters $0.1 \%, 0.3 \%$ and $0.5 \%$ on ice cream with $15 \%$ canistel flour had each overrun value were $50.00 \%, 57.14 \%$, and 64, 28\%; cream separation value on emulsion stability were $0,250 \mathrm{~cm}, 0,150 \mathrm{~cm}$, and $0,150 \mathrm{~cm}$; melting point in 30.02 minutes, 33.33 minutes, and 36.13 minutes; viscocity in $16560 \mathrm{cP}, 17020 \mathrm{cP}$, and $17380 \mathrm{cP}$; and total dissolved solids value were $33.62 \%, 34.47 \%$, and $39.98 \%$. Addition of sucrose esters to the ice cream with $10 \%$ canistel flour resulted hedonic acceptance neither like nor dislike-like for color, like for texture and flavor, and neither like nor dislike for aroma. The addition of sucrose esters to the addition of $15 \%$ canistel flour resulted hedonic acceptance like-very like for color; neither like nor dislike for texture, flavor and aroma.
\end{abstract}

Keywords: ice cream, canistel, sucrose ester 


\section{PENDAHULUAN}

Es krim merupakan makanan beku berbahan baku susu yang dibuat dengan membekukan campuran yang telah dipasteurisasi dengan agitasi (pengadukan) untuk memasukan udara dan memastikan konsistensi keseragaman campuran bahan pembuat es krim (Arbuckle, 1986). Es krim termasuk produk emulsi minyak dalam air yang menghasilkan struktur busa (gas yang terdispersi dalam cairan) (Ismunandar, 2004). Es krim dengan penambahan buah menjadi salah satu produk yang selalu mengalami pengembangan atau diversifikasi. Salah satu es krim dengan bahan buahbuahan adalah es krim tepung buah sawo mentega yang diteliti oleh Yuliana (2018). Karakteristik organoleptik es krim yang dihasilkan cenderung agak tidak disukai. Es krim dengan penambahan tepung buah sawo mentega $10 \%$ dan $15 \%$ menghasilkan karakteristik warna, tekstur, aroma dan rasa yang cenderung agak tidak disukai.

Es krim yang dibuat oleh Yuliana (2018) menggunakan kuning telur sebagai emulsifier. Jumlah emulsifier yang digunakan sebanyak $0,1 \%$ dari berat adonan. Penambahan kuning telur sebagai emulsifier memberikan peran dalam memperbaiki sifat es krim yang tidak baik pada es krim (Ismunandar, 2004). Namun, penambahan kuning telur sebagai emulsifier alami memberikan reaksi alergi terhadap beberapa orang, dan penggunaan kuning membuat biaya produksi relatif lebih tinggi apabila dibandingkan dengan emulsifier sintesis (Iteh, 2012). Jenis emulsifier selain kuning telur yaitu lesitin kedelai, serta emulsifier sintetis seperti monogliserida/digliserida, ester sukrosa, sorbitan tristearat, poligliserol esters dan polisorbat 80 (Friberg, 2005).

Emulsifier sintetis yang ditambahkan ke dalam es krim dapat mendispersikan globula lemak dengan lebih efektif. Penelitian yang dilakukan oleh Iteh (2012) mengenai penggunaan ester sukrosa atau mono/di-gliserida dibandingkan dengan kuning telur dalam memperbaiki beberapa karakteristik fisik es krim, meningkatkan overrun dari $44,29 \%$ menjadi $94,87 \%$, kekentalan dari $8,83 \mathrm{dPa}$.S menjadi 11,67 dPa.S, kestabilan emulsi dari $77,30 \%$ menjadi $90,59 \%$ dan meningkatkan waktu pelelehan dari 69,67 menit menjadi 133,83 menit.

Berdasarkan hasil tersebut, penggunaan ester sukrosa diperkirakan dapat memperbaiki karakteristik fisik dan organoleptik es krim tepung buah sawo mentega. Penelitian ini menggunakan tepung sawo mentega $10 \%$ dan $15 \%$ sebagai faktor kedua sebagai pembanding. Maka dari itu, tujuan penelitian ini adalah untuk mengetahui penggunaan ester sukrosa terhadap karakteristik fisik dan organoleptik es krim tepung sawo mentega.

\section{METODE PENELITIAN}

Metode penelitian yang digunakan adalah eksperimen dengan rancangan acak kelompok faktorial yang diulang sebanyak dua kali. Faktor perlakuan pertama adalah penambahan tepung buah sawo mentega dengan dua taraf yaitu $10 \%$ dan $15 \%$. Faktor kedua adalah penambahan emulsifier dengan tiga taraf yaitu ester sukrosa $0,1 \%, 0,3 \%$, dan $0,5 \%$.

Bahan yang digunakan untuk produksi es krim buah sawo mentega adalah buah sawo mentega setengah matang, susu sapi segar, susu skim cair, whipped cream, CMC, gula, dan ester sukrosa. Alat yang digunakan dalam produksi es krim buah sawo mentega adalah refrigerator, oven pengering, sentrifus, Brookfield viscometer, panci pengukus, timbangan bahan, hot plate, mixer, grinder, pengayak 60 mesh, mangkuk, gelas ukur, gelas beaker, clip bench, termometer, refrakometer, talenan, pisau, sendok, cawan petri, stopwatch, dan kemasan cup.

\section{Pembuatan tepung buah sawo mentega (Khoirunnisa, 2016)}

1. Buah sawo mentega ditimbang dan dicuci dengan air untuk menghilangkan kotoran.

2. Kulit buah sawo mentega dikupas, kemudian daging buah sawo mentega diiris tipis dengan tingkat ketebalan $1 \mathrm{~cm}$.

3. Buah sawo mentega yang telah diiris kemudian dilakukan blansing dengan cara steaming blansing untuk mempertahankan warna dalam suhu $85^{\circ} \mathrm{C}$ selama 7 menit, buah sawo mentega ditiriskan, dan disusun dalam loyang.

4. Buah campolai dikeringkan pada suhu $45^{\circ} \mathrm{C}$ menggunakan oven pengering selama 13 jam. 
5. Setelah proses pengeringan dilakukan, buah sawo mentega pada loyang dihaluskan dengan menggunakan grinder untuk menghasilkan tepung sawo mentega dengan ukuran 60 mesh.

Pembuatan Es Krim Tepung Buah Sawo Mentega (Yuliana, 2018)

1. Melakukan pasteurisasi $300 \mathrm{ml}$ susu sapi segar $60^{\circ} \mathrm{C}$ selama 30 menit.

2. Mendinginkan susu hasil pasteurisasi hingga mencapai $40^{\circ} \mathrm{C}$.

3. Mencampurkan bahan pendukung seperti susu skim $5 \%(\mathrm{~b} / \mathrm{v})$. Tepung buah sawo mentega $(10 \%, 15 \%)$, sukrosa $15 \%(\mathrm{~b} / \mathrm{v}), \mathrm{CMC}$ (carboxyl methylcellulose) $1 \%(\mathrm{~b} / \mathrm{v})$ whipped cream $5 \%$ $(\mathrm{b} / \mathrm{v})$, ester sukrosa $(0,1 \%, 0,3 \%$, dan $0,5 \%)$.

4. Homogensiasi adonan dengan mixer kecepatan 2 dari skala kecepatan (1-4) selama 15 menit.

5. Melakukan aging pada suhu $\left(-20^{\circ} \mathrm{C}\right)$ selama $12 \mathrm{jam}$.

6. Homogenisasi dengan mixer selama 30 menit.

7. Memasukkan es krim dalam kemasan cup es krim.

8. Menyimpan dalam freezer dengan suhu $\left(-20^{\circ} \mathrm{C}\right)$.

Waktu Leleh es krim (Zahro dan Nisa, 2015).

1. Suhu dan kelembaban ruangan diukur.

2. Sebagaian es krim diambil dengan berat yang sergam, dan ditempatkan pada cawan petri lalu dibekukan dalam freezer selama 24 jam.

3. Sampel dari freezer diambil dan diletakkan pada suhu kamar dan dibiarkan hingga seluruh sampel meleleh (es krim meleleh mengikuti bentuk wadah).

4. Waktu yang dibutuhkan hingga seluruh sampel meleleh dicatat dan selanjutnya dianalisis secara statistik.

Overrun es krim (Clarke, 2012)

Overrun adalah perhitungan industri untuk menghitung udara yang bertambah pada produk makanan penutup beku, dan dihitung dalam bentuk persentase peningkatan volume yang terjadi sebagaai akibat dari penambahan udara.

Stabilitas Emulsi (Anwar, dkk, 2017)

$$
\% \text { Overrun }=\frac{\text { Volume es krim }- \text { volume adonan es krim }}{\text { volume adonan es krim }} \times 100 \%
$$

Stabilitas emulsi diukur dengan metode sentrifugasi pada sampel yang disimpan selama 14 hari, pengujian stabilitas emulsi dilakukan dengan langkah sebagai berikut:

1. Sampel sebanyak $8 \mathrm{~cm}$ dimasukkan ke dalam tabung sentrifus.

2. Disentrifugasi pada kecepatan $4000 \mathrm{rpm}$ selama 5 menit.

3. Perhitungan stabilitas emulsi berdasarkan pemisahan tinggi krim.

Viskositas (Zahro dan Nisa, 2015)

Viskositas diukur dengan menggunakan Brookfield viscometer, dengan langkah sebagai berikut:

1. Kalibrasi Brookfield viscometer.

2. Sampel diletakkan dalam gelas beaker $250 \mathrm{ml}$.

3. Jarum spindle no. 6 dipasang pada viscometer dan diatur kecepatan putarannya pada $60 \mathrm{rpm}$.

4. Skala yang ditunjuk oleh alat dibaca setelah jumlah putaran tertentu.

Total Padatan Terlarut (TPT)

Pengukuran total padatan terlarut dilakukan menggunakan refraktometer tipe Master-TM pada suhu ruang dan dilakukan kalibrasi menggunakan aquades, sebanyak 1-2 gram sampel dimasukkan ke dalam prisma refractometer dan jumlah kandungan padatan terlarut dinyatakn sebagai persen (\%) atau ${ }^{\circ}$ Brix.

\section{Uji Organoleptik (Uji hedonik)}

Uji organoleptik tingkat kesukaan (hedonik) meliputi warna, aroma, rasa, dan tekstur. Uji hedonik pada penelitian ini menggunakan 15 panelis semi terlatih. Panelis menilai sampel yang diberi kode secara acak dengan skala pengujian hedonik yang memiliki rentang skor 1-5 (tidak suka - sangat suka). 


\section{HASIL DAN PEMBAHASAN}

\section{Karakteristik Fisik Es Krim}

\section{a. Waktu Leleh}

Berdasarkan analisis ragam, penambahan tepung sawo mentega dan ester sukrosa berpengaruh nyata pada nilai waktu leleh es krim yang dihasilkan. Nilai waktu leleh es krim tepung sawo mentega tersaji pada Gambar 1. Pengaruh tepung sawo mentega terhadap waktu leleh dapat tersaji pada Tabel 1. Pengaruh ester sukrosa terhadap waktu leleh dapat dilihat pada Tabel 2.

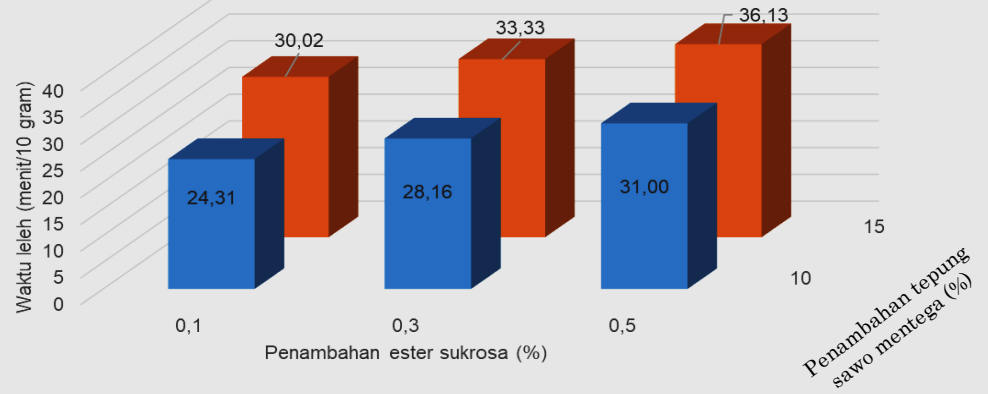

Gambar 1. Nilai Waktu Leleh Es Krim Tepung Sawo Mentega

Tabel 1. Pengaruh Tepung Sawo Mentega terhadap Waktu Leleh

\begin{tabular}{cc}
\hline Konsentrasi Tepung Sawo Mentega & Rataan Perlakuan (menit/10 gram) \\
\hline $10 \%$ & $27,93^{\mathrm{a}}$ \\
\hline $15 \%$ & $33,26^{\mathrm{b}}$ \\
\hline
\end{tabular}

Keterangan: Notasi yang sama menunjukkan tidak berbeda nyata menurut Uji Duncan pada taraf signifikan $\alpha=5 \%$.

Tabel 2. Pengaruh Ester Sukrosa terhadap Waktu Leleh

\begin{tabular}{cc}
\hline Konsentrasi Ester Sukrosa & Rataan Perlakuan (menit/10 gram) \\
\hline $0,1 \%$ & $27,28^{\mathrm{a}}$ \\
\hline $0,3 \%$ & $30,90^{\mathrm{b}}$ \\
\hline $0,5 \%$ & $33,61^{\mathrm{c}}$ \\
\hline
\end{tabular}

Keterangan: Notasi yang sama menunjukkan tidak berbeda nyata menurut Uji Duncan pada taraf signifikan $\alpha=5 \%$.

Berdasarkan Tabel 2, tiap penambahan ester sukrosa menghasilkan waktu leleh yang cenderung meningkat, emulsifier dapat meningkatkan kemampuan pengadukan lemak dan air, sehingga pencampuran yang merata dapat memperlambat pencairan es krim (Chan, 2008). Penambahan tepung sawo mentega menghasilkan waktu leleh es krim yang cenderung meningkat. Penambahan tepung sawo mentega menyebabkan total padatan meningkat. Total padatan yang tinggi akan menyebabkan kandungan dalam air lebih sedikit, kristal es yang terbentuk sedikit sehingga es krim lebih tahan terhadap pelelehan (Ermawati, dkk, 2016).

Penambahan ester sukrosa cenderung meningkatkan waktu leleh es krim. Nilai waktu leleh es krim tepung sawo mentega berkisar 24,31 - 36,13 menit. Nilai tersebut lebih besar dari ketentuan daya leleh es krim yaitu 10-15 menit (Bodyfelt dkk, 1988).

\section{b. Overrun}

Berdasarkan analisis ragam, penambahan tepung sawo mentega dan ester sukrosa berpengaruh nyata pada nilai overrun es krim yang dihasilkan. Nilai overrun es krim tepung sawo mentega dapat dilihat pada Gambar 2. Pengaruh tepung sawo mentega terhadap overrun dapat dilihat pada Tabel 3. Pengaruh ester sukrosa terhadap overrun dapat dilihat pada Tabel 4. 


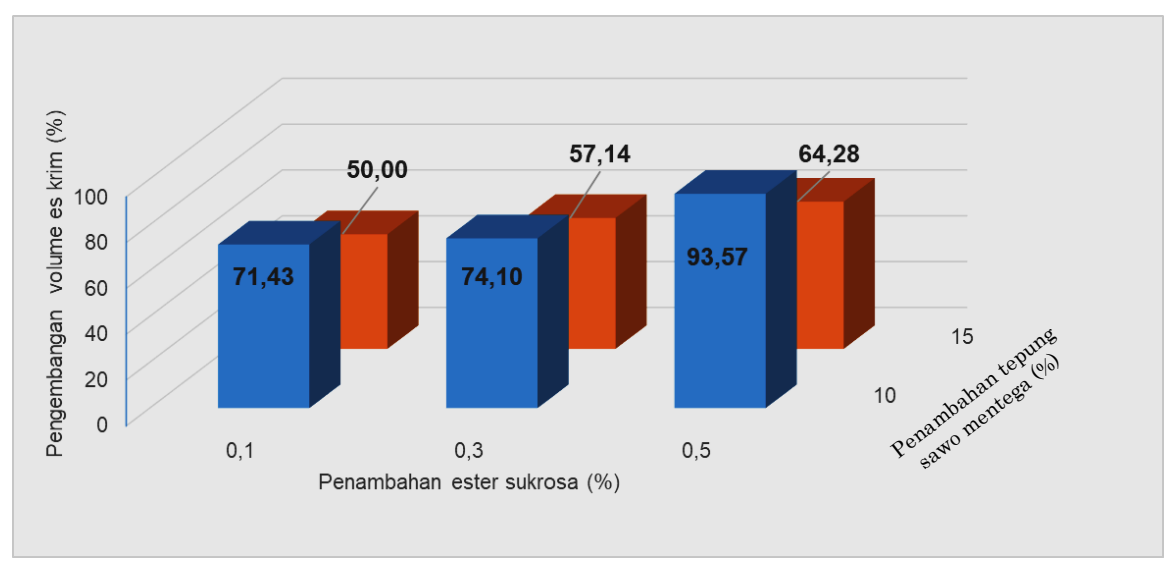

Gambar 2. Nilai Overrun Es Krim Tepung Sawo Mentega

Tabel 3. Pengaruh Tepung Sawo Mentega terhadap Overrun

\begin{tabular}{cc}
\hline Konsentrasi Tepung Sawo Mentega & Rataan Perlakuan (\%) \\
\hline $10 \%$ & $79,70^{\mathrm{b}}$ \\
\hline $15 \%$ & $57,14^{\mathrm{a}}$ \\
\hline
\end{tabular}

Keterangan: Notasi yang sama menunjukkan tidak berbeda nyata menurut Uji Duncan pada taraf signifikan $\alpha=5 \%$.

Tabel 4. Pengaruh Ester Sukrosa terhadap Overrun

\begin{tabular}{cc}
\hline Konsentrasi Ester Sukrosa & Rataan Perlakuan (\%) \\
\hline $0,1 \%$ & $60,72^{\mathrm{a}}$ \\
\hline $0,3 \%$ & $65,62^{\mathrm{ab}}$ \\
\hline $0,5 \%$ & $78,93^{\mathrm{b}}$ \\
\hline
\end{tabular}

Keterangan: Notasi yang sama menunjukkan tidak berbeda nyata menurut Uji Duncan pada taraf signifikan $\alpha=5 \%$.

Berdasarkan Tabel 6, penambahan ester sukrosa pada penambahan tepung sawo mentega $10 \%$ dan $15 \%$ overrun yang dihasilkan cenderung meningkat, hal ini sesuai dengan pernyataan Chan (2008) bahwa penggunaan emulsifier pada es krim dapat mengembangakan adonan es krim (overrun). Emulsifier dapat menurunkan tegangan permukaan antara lemak dan cairan pada sistem koloid (Arbuckle, 1961), sehingga udara mudah masuk dan membentuk foam. Sedangkan penambahan tepung menurunkan overrun es krim karena semakin banyak jumlah tepung sawo mentega pada adonan es krim maka adonan es krim akan menjadi lebih kental sehingga sulit untuk diaduk oleh pengaduk, dan udara yang terperangkap menjadi sedikit dan nilai overrun mengecil (Sakawulan, 2004).

Es krim tepung sawo mentega termasuk fruit ices, nilai overrun es krim tepung sawo mentega berkisar 50\%-93,57\%, nilai tersebut lebih besar dari overrun fruit ices yaitu $20 \%-25 \%$ (Arbuckle, 1961) dan termasuk kedalam tipe es krim standar yaitu dengan nilai overrun $60 \%-90 \%$ (McGee, 2004).

\section{c. Stabilitas emulsi}

Berdasarkan analisis ragam, penambahan tepung sawo mentega dan ester sukrosa berpengaruh nyata pada nilai stabilitas es krim yang dihasilkan. Nilai stabilitas es krim tepung sawo mentega dapat dilihat pada Gambar 3. Pengaruh tepung sawo mentega terhadap stabilitas emulsi dapat dilihat pada Tabel 5. Pengaruh ester sukrosa terhadap stabilitas emulsi dapat dilihat pada Tabel 6. 


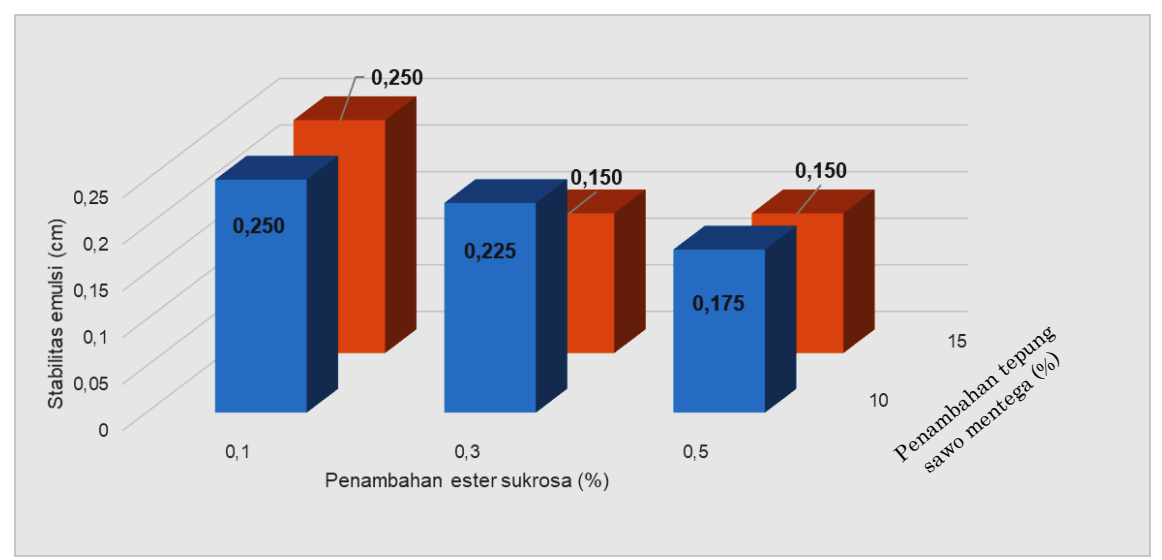

Gambar 3. Nilai Stabilitas Emulsi Es Krim Tepung Sawo Mentega

Tabel 5. Pengaruh Tepung Sawo Mentega terhadap Stabilitas Emulsi Es krim Tepung Sawo Mentega

\begin{tabular}{cc}
\hline Konsentrasi Tepung Sawo Mentega & Rataan Perlakuan (\%) \\
\hline $10 \%$ & $0,0271^{\mathrm{a}}$ \\
\hline $15 \%$ & $0,0229^{\mathrm{a}}$ \\
\hline
\end{tabular}

Keterangan: Notasi yang sama menunjukkan tidak berbeda nyata menurut Uji Duncan pada taraf signifikan $\alpha=5 \%$.

Tabel 6. Pengaruh Ester Sukrosa terhadap Stabilitas Emulsi Es Krim Tepung Sawo Mentega

\begin{tabular}{cc}
\hline Konsentrasi Ester Sukrosa & Rataan Perlakuan (\%) \\
\hline $0,1 \%$ & $0,0313^{\mathrm{b}}$ \\
\hline $0,3 \%$ & $0,0234^{\mathrm{ab}}$ \\
\hline $0,5 \%$ & $0,0203^{\mathrm{a}}$ \\
\hline
\end{tabular}

Keterangan: Notasi yang sama menunjukkan tidak berbeda nyata menurut Uji Duncan pada taraf signifikan $\alpha=5 \%$.

Berdasarkan Tabel 6, penambahan ester sukrosa berbeda nyata terhadap stabilitas emulsi. Tiap penambahan konsentrasi ester sukrosa menghasilkan tinggi pemisahan krim yang sedikit sehingga stabilitas emulsi yang dihasilkan tinggi. Es krim merupakan tipe emulsi minyak dalam air, tipe emulsi minyak dalam air pada es krim membutuhkan HLB dengan rentang 15-16 (MitsubishiChemical Food, 2019), ester sukrosa memiliki memiliki HLB (Hydophifil-lipophifil balance) dengan rentang 12-16 (Whitehurst, 2004), sehingga penggunaan ester sukrosa selaras untuk pembuatan es krim. HLB yang tinggi memiliki kemampuan untuk menstabilkan struktur globula lemak dalam emulsi (McClement, 2005). Penambahan tepung sawo mentega menghasilkan stabilitas emulsi yang cenderung meningkat. Rauf dan Sarbini (2015) menyatakan kecenderungan dalam kenaikan daya serap air tepung singkong, yaitu semakin tinggi porsi tepung singkong, maka semakin tinggi pula daya serap airnya, sehingga semakin banyak penambahan tepung sawo mentega pada es krim maka penyerapan airnya pun semakin tinggi sehingga membuat struktur yang kokoh.

\section{d. Viskositas}

Berdasarkan analisis ragam, penambahan tepung sawo mentega dan ester sukrosa berpengaruh nyata terhadap viskositas es krim, serta berpengaruh nyata terhadap interaksi antara tepung sawo mentega dan ester sukrosa. Nilai viskositas es krim tepung sawo mentega dapat dilihat pada Gambar 4. Pengaruh Interaksi konsentrasi tepung sawo mentega dan konsentrasi ester sukrosa terhadap viskositas es krim tepung sawo mentega dapat dilihat pada Tabel 7 . 


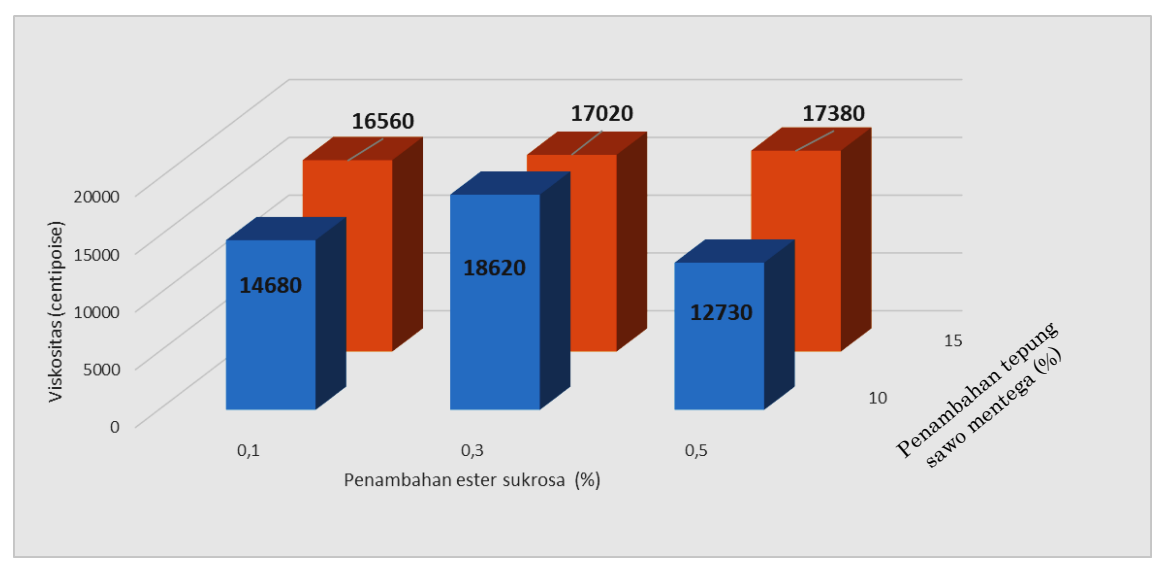

Gambar 4. Nilai Viskositas Es Krim Tepung Sawo Mentega

Tabel 7. Pengaruh Interaksi Konsentrasi Tepung Sawo Mentega dan Konsentrasi Ester Sukrosa terhadap Viskositas Es Krim Tepung Sawo Mentega

\begin{tabular}{cccc}
\hline \multirow{2}{*}{$\begin{array}{c}\text { Konsentrasi Tepung } \\
\text { Sawo Mentega }\end{array}$} & \multicolumn{3}{c}{ Konsentrasi Ester Sukrosa } \\
\cline { 2 - 4 } & $\mathbf{0 , 1 \%}$ & $\mathbf{0 , 3} \%$ & $\mathbf{0 , 5 \%}$ \\
\hline \multirow{2}{*}{$10 \%$} & $14680 \mathrm{~A}$ & $18620 \mathrm{~B}$ & $12730 \mathrm{~A}$ \\
\hline \multirow{2}{*}{$15 \%$} & $\mathrm{~b}$ & $\mathrm{c}$ & $\mathrm{a}$ \\
\cline { 2 - 4 } & $16560 \mathrm{~B}$ & $17020 \mathrm{~A}$ & $17380 \mathrm{~B}$ \\
\hline
\end{tabular}

Keterangan: Angka yang diikuti huruf yang sama tidak berbeda nyata menurut uji Duncan pada taraf signifikan $\alpha=5 \%$. Huruf kapital dibaca berdasarkan kolom dan huruf kecil dibaca berdasarkan baris.

Berdasarkan Tabel 7, penambahan ester sukrosa $0,3 \%$ pada penambahan tepung sawo mentega $10 \%$ memiliki viskositas yang tinggi dibandingkan dengan yang lain, dan penambahan ester sukrosa $0,5 \%$ memiliki viskositas terendah. Viskositas menjadi turun setelah pengadukan disebabkan perubahan granula pati untuk mengikat air (Sakawulan, dkk, 2004). Hal ini disebabkan juga dari emulsifier yang memiliki kemampuan untuk meningkatkan pengadukan (Chan, 2008), sehingga viskositas es krim cenderung menurun.

Penambahan tepung sawo mentega membuat viskositas bertambah. Muse dan Hartel (2004) menjelaskan bahwa viskositas produk beku akan meningkat dengan penambahan polisakarida berbobot molekul yang tinggi seperti pati. Tepung sawo mentega memiliki kadar karbohidrat $92,44 \%$ (Khoirunnisa, 2016), sehingga tepung sawo mentega mampu meningkatkan viskositas es krim. Menurut Sakawulan, dkk (2004) velva harus memiliki viskositas yang tidak terlalu besar agar dalam pembuatannya tidak memerlukan energi tinggi yang membebankan pengaduk.

\section{e. Total Padatan Terlarut}

Berdasarkan analisis ragam, penambahan tepung sawo mentega dan ester sukrosa berpengaruh nyata terhadap total padatan terlarut es krim, serta berpengaruh nyata terhadap interaksi antara tepung sawo mentega dan ester sukrosa. Nilai total padatan terlarut es krim tepung sawo mentega dapat dilihat pada Gambar 5. Pengaruh Interaksi konsentrasi tepung sawo mentega dan konsentrasi ester sukrosa terhadap total padatan terlarut es krim tepung sawo mentega dapat dilihat pada Tabel 8. 


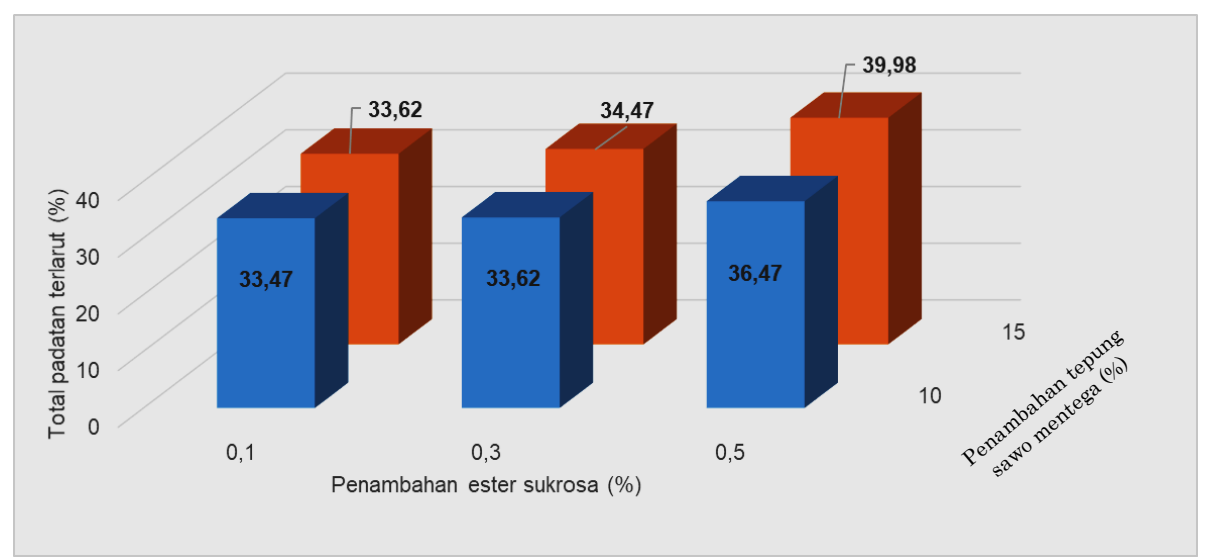

Gambar 5. Nilai Total Padatan Terlarut Es Krim Tepung Sawo Mentega

Tabel 8. Pengaruh Interaksi Konsentrasi Tepung Sawo Mentega dan Konsentrasi Ester Sukrosa terhadap Total Padatan Terlarut Es Krim Tepung Sawo Mentega

\begin{tabular}{cccc}
\hline \multirow{2}{*}{$\begin{array}{c}\text { Konsentrasi Tepung } \\
\text { Sawo Mentega }\end{array}$} & \multicolumn{3}{c}{ Konsentrasi Ester Sukrosa } \\
\cline { 2 - 4 } & $\mathbf{0 , 1 \%}$ & $\mathbf{0 , 3 \%}$ & $\mathbf{0 , 5 \%}$ \\
\cline { 2 - 4 } $10 \%$ & $33.47 \mathrm{~A}$ & $33.62 \mathrm{~A}$ & $36.472 \mathrm{~A}$ \\
\cline { 2 - 4 } & $\mathrm{a}$ & $\mathrm{a}$ & $\mathrm{b}$ \\
\cline { 2 - 4 } & $33.62 \mathrm{~A}$ & $34.47 \mathrm{~A}$ & $39.979 \mathrm{~B}$ \\
& $\mathrm{a}$ & $\mathrm{a}$ & $\mathrm{b}$ \\
\hline
\end{tabular}

Keterangan: Angka yang diikuti huruf yang sama tidak berbeda nyata menurut uji Duncan pada taraf signifikan $\alpha=5 \%$. Huruf kapital dibaca berdasarkan kolom dan huruf kecil dibaca berdasarkan baris.

Berdasarkan Tabel 8, penambahan ester sukrosa menghasilkan total padatan terlarut yang cenderung meningkat. Ester sukrosa terbentuk akibat dari esterifikasi asam lemak dengan gula atau dengan cara transesterifikasi gula dan gliserida yang dijadikan sebagai campuran gliserida (Friberg, dkk, 2005). Total padatan terlarut pada es krim meliputi kadar lemak, kadar protein, dan kadar karbohidrat (Filiyanti, dkk, 2013) sehingga padatan ester sukrosa terhitung pada refraktometer. Penambahan tepung sawo mentega cenderung meningkatkan total padatan terlarut es krim. Tepung sawo mentega dapat meningkatkan total padatan terlarut akibat dari komponen tepung seperti amilosa dan amilopektin terdegradasi sehingga keluar dari granula pati (Sakawulan, dkk, 2014). Padatan terlarut es krim tepung sawo mentega memiliki nilai berkisar $33,47 \%-39,98 \%$, nilai padatan tersebut lebih besar dari padatan terlarut minimum 3,4\% (SNI, 1995) sehingga semua formulasi sudah sesuai dengan SNI.

\section{Karakteristik Sensori Es Krim}

\section{a. Warna}

Berdasarkan rata-rata skor hedonik warna es krim tepung sawo mentega dapat dilihat pada Gambar 6. Perbandingan skor hedonik warna es krim tepung sawo mentega dapat dilihat pada Tabel 9.

Tabel 9. Perbandingan Skor Hedonik Warna Es Krim Tepung Sawo Mentega

\begin{tabular}{|c|c|c|c|c|}
\hline \multirow{2}{*}{$\begin{array}{l}\text { Konsentrasi } \\
\text { Tepung Sawo } \\
\text { mentega }\end{array}$} & \multicolumn{3}{|c|}{ Konsentrasi Ester Sukrosa } & \multirow{2}{*}{$\begin{array}{c}\text { Es Krim Tepung Sawo Mentega } \\
\text { dengan Kuning Telur } \\
\text { (Yuliana, 2018) }\end{array}$} \\
\hline & $0,1 \%$ & $0,3 \%$ & $0,5 \%$ & \\
\hline $10 \%$ & $\begin{array}{c}3,93 \\
\text { (suka) }\end{array}$ & $\begin{array}{l}3,93 \\
\text { (suka) }\end{array}$ & $\begin{array}{c}3,37 \\
\text { (biasa) }\end{array}$ & $\begin{array}{c}2,01 \\
\text { (agak tidak suka) }\end{array}$ \\
\hline $15 \%$ & $\begin{array}{c}3,87 \\
\text { (suka) }\end{array}$ & $\begin{array}{c}4,37 \\
\text { (sangat suka) }\end{array}$ & $\begin{array}{c}3,70 \\
\text { (suka) }\end{array}$ & $\begin{array}{c}1,98 \\
\text { (agak tidak suka) }\end{array}$ \\
\hline
\end{tabular}




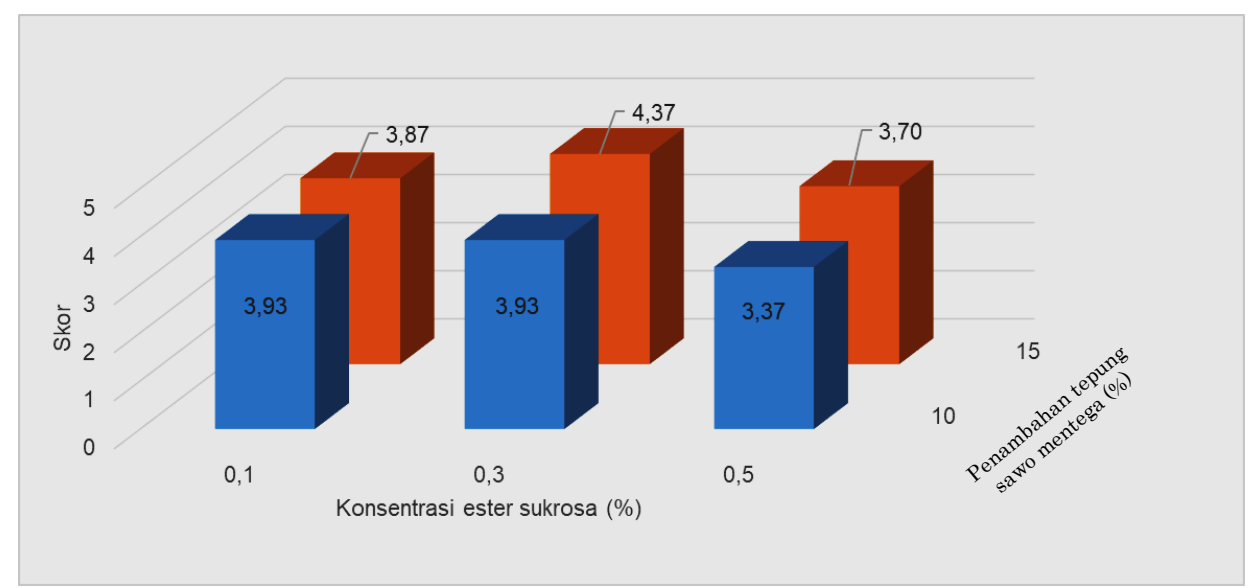

Gambar 6. Skor Hedonik Warna Es Krim Tepung Sawo Mentega

Berdasarkan Tabel 9, penambahan ester sukrosa memiliki nilai kesukaan yang bervariasi, namun kesukaan warna cenderung turun. Berdasarkan Tabel 10, skor hedonik warna es krim tepung sawo mentega berkisar 3,17-4,37 yang termasuk kategori biasa-sangat suka. Warna yang dihasilkan ester sukrosa terbentuk akibat dari esterifikasi asam lemak dengan gula atau dengan cara transesterifikasi gula dan gliserida yang dijadikan sebagai campuran gliserida (Friberg, dkk, 2005). Tepung sawo mentega memiliki warna kuning pada daging buahnya, warna kuning tersebut berasal dari asam lemak yang mengandung karoten (Muchtadi, dkk, 2015). Penambahan ester sukrosa $0,5 \%$ memiliki skor hedonik terendah, warna yang dihasilkan berkurang akibat penambahan volume es krim (overrun), semakin tinggi overrun maka warna yang dihasilkan semakin memudar.

\section{b. Aroma}

Berdasarkan rata-rata skor hedonik aroma es krim tepung sawo mentega dapat dilihat pada Gambar 7. Perbandingan skor hedonik aroma es krim tepung sawo mentega dapat dilihat pada Tabel 10.

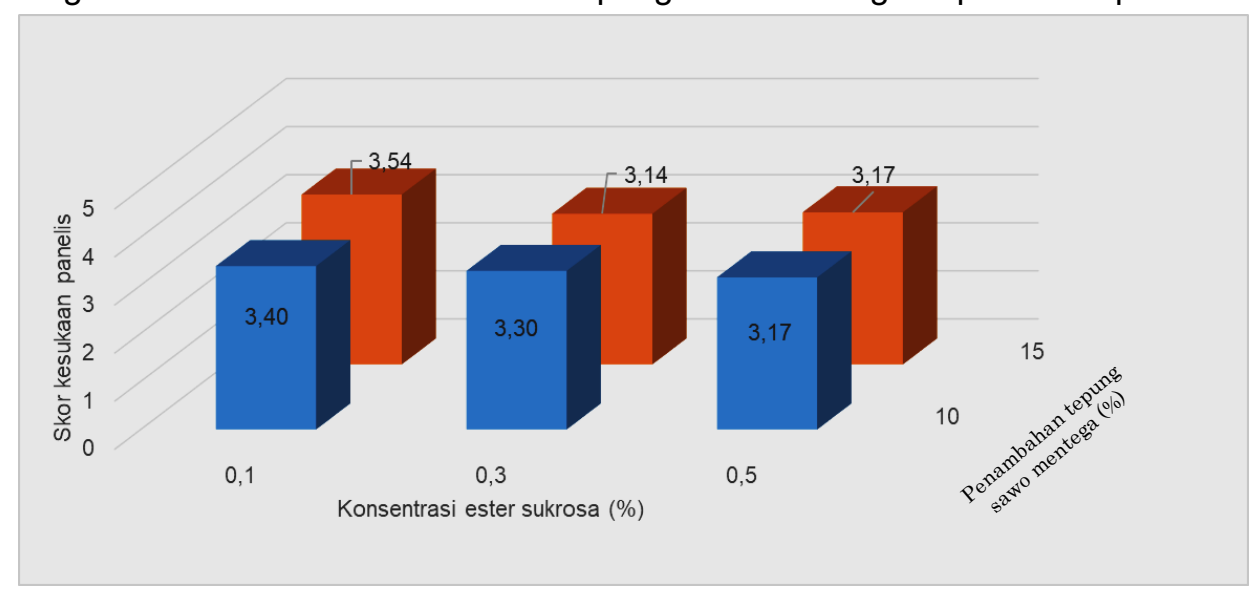

Gambar 7. Skor Hedonik Aroma Es Krim Tepung Sawo Mentega

Tabel 10. Perbandingan Skor Hedonik Aroma Es Krim Tepung Sawo Mentega

\begin{tabular}{|c|c|c|c|c|}
\hline \multirow{2}{*}{$\begin{array}{l}\text { Konsentrasi Tepung } \\
\text { Sawo mentega }\end{array}$} & \multicolumn{3}{|c|}{ Konsentrasi Ester Sukrosa } & \multirow{2}{*}{$\begin{array}{c}\text { Es Krim Tepung Sawo Mentega } \\
\text { dengan Kuning Telur } \\
\text { (Yuliana, 2018) }\end{array}$} \\
\hline & $0,1 \%$ & $0,3 \%$ & $0,5 \%$ & \\
\hline $10 \%$ & $\begin{array}{c}3,40 \\
\text { (biasa) }\end{array}$ & $\begin{array}{c}3,30 \\
\text { (biasa) }\end{array}$ & $\begin{array}{c}3,17 \\
\text { (biasa) }\end{array}$ & $\begin{array}{c}1,94 \\
\text { (agak tidak suka) }\end{array}$ \\
\hline $15 \%$ & $\begin{array}{c}3,54 \\
\text { (suka) }\end{array}$ & $\begin{array}{c}3,14 \\
\text { (biasa) }\end{array}$ & $\begin{array}{c}3,17 \\
\text { (biasa) }\end{array}$ & $\begin{array}{c}1,97 \\
\text { (agak tidak suka) }\end{array}$ \\
\hline
\end{tabular}


Berdasarkan Tabel 10, aroma es krim memiliki skor hedonik aroma berkisar 3,14-3,54 yang termasuk dalam kategori biasa-suka. ester sukrosa tidak memiliki aroma (Szüts, 2012), sehingga tidak memberikan pengaruh pada aroma es krim tepung sawo mentega. Berdasarkan Gambar 7, penambahan tepung membuat aroma cenderung meningkat, karena jumlah tepung yang ditambahkan banyak maka komponen aroma yang dihasilkan lebih banyak.

\section{c. Rasa}

Berdasarkan rata-rata skor hedonik rasa es krim dapat dilihat pada Gambar 8. Perbandingan skor hedonik rasa es krim tepung sawo mentega dapat dilihat pada Tabel 11.

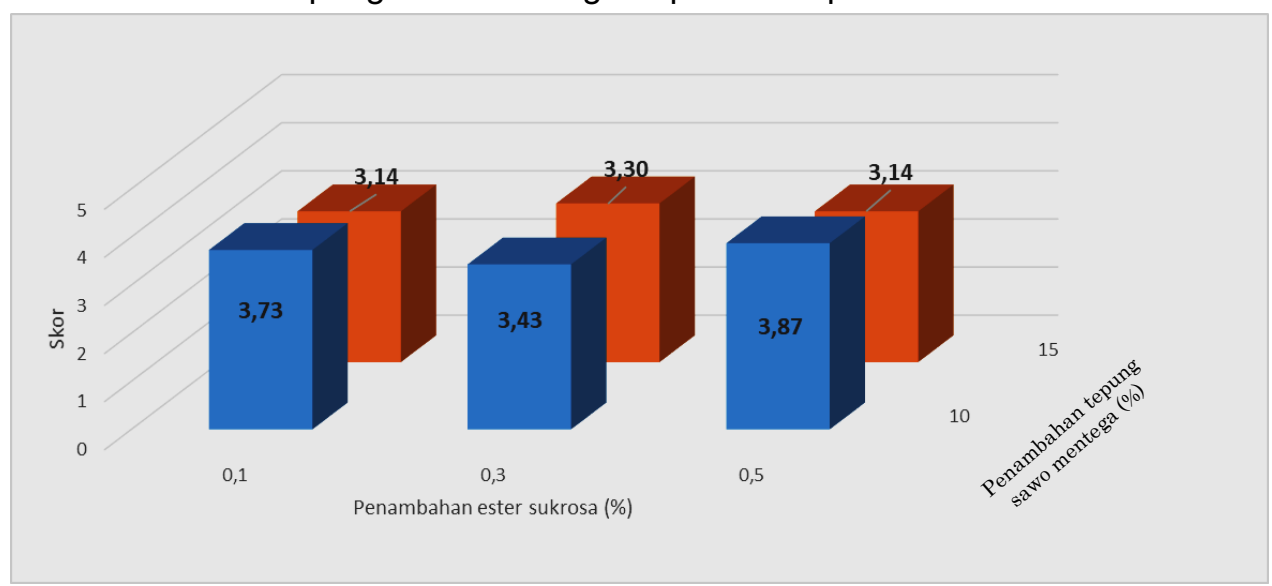

Gambar 8. Skor Hedonik Rasa Es Krim Tepung Sawo Mentega

Tabel 11. Perbandingan Skor Hedonik Rasa Es Krim Tepung Sawo Mentega

\begin{tabular}{|c|c|c|c|c|}
\hline \multirow{2}{*}{$\begin{array}{l}\text { Konsentrasi Tepung } \\
\text { Sawo mentega }\end{array}$} & \multicolumn{3}{|c|}{ Konsentrasi Ester Sukrosa } & \multirow{2}{*}{$\begin{array}{c}\text { Es Krim Tepung Sawo Mentega } \\
\text { dengan Kuning Telur } \\
\text { (Yuliana, 2018) }\end{array}$} \\
\hline & $0,1 \%$ & $0,3 \%$ & $0,5 \%$ & \\
\hline $10 \%$ & $\begin{array}{c}3,73 \\
\text { (suka) }\end{array}$ & $\begin{array}{l}3,43 \\
\text { (suka) }\end{array}$ & $\begin{array}{l}3,87 \\
\text { (suka) }\end{array}$ & $\begin{array}{c}2,19 \\
\text { (agak tidak suka) }\end{array}$ \\
\hline $15 \%$ & $\begin{array}{c}3,14 \\
\text { (biasa) }\end{array}$ & $\begin{array}{c}3,30 \\
\text { (biasa) }\end{array}$ & $\begin{array}{c}3,14 \\
\text { (biasa) }\end{array}$ & $\begin{array}{c}2,22 \\
\text { (agak tidak suka) }\end{array}$ \\
\hline
\end{tabular}

Berdasarkan Tabel 11, es krim dengan penambahan tepung sawo mentega 10\% lebih disukai dibandingkan dengan penambahan tepung sawo mentega $15 \%$. Hal ini terjadi karena tepung sawo mentega memiliki rasa yang hambar karena buah sawo mentega yang digunakan belum terlalu matang sehingga belum terjadinya pemutusan ikatan karbohidrat kompleks akibat respirasi yang membuat karbohidrat kompleks terpecah menjadi karbohidrat sederhana yang memiliki rasa manis (Sunila dan Murugan, 2017). Hal ini membuat penambahan tepung sawo mentega mengurangi rasa dari es krim. Sedangkan penambahan ester sukrosa memiliki karakteristik yang tidak berasa (Szüts, 2012) sehingga tidak mempengaruhi rasa pada es krim tepung sawo mentega. Berdasarkan ratarata skor hedonik rasa dengan rentang 3,14-3,87 termasuk kategori biasa-suka.

\section{d. Tekstur}

Berdasarkan rata-rata skor hedonik tekstur es krim tepung sawo mentega dapat dilihat pada Gambar 9. Perbandingan skor hedonik tekstur es krim tepung sawo mentega dapat dilihat pada Tabel 12. 


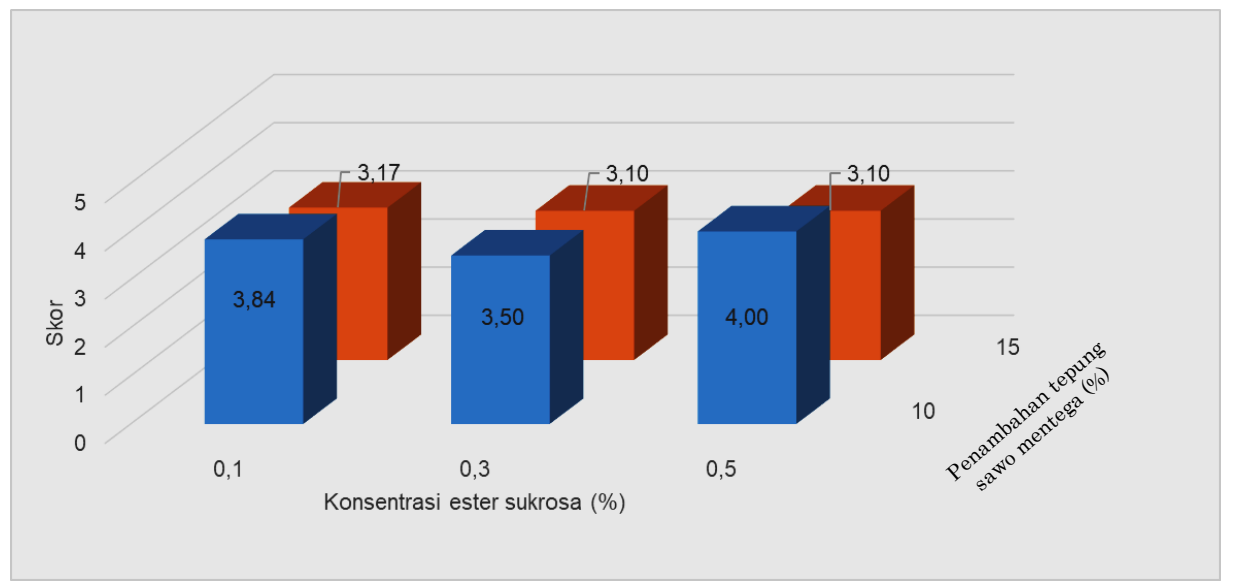

Gambar 9. Skor Hedonik Tekstur Es Krim Tepung Sawo Mentega

Tabel 12. Perbandingan Skor Hedonik Tekstur Es Krim Tepung Sawo Mentega

\begin{tabular}{|c|c|c|c|c|}
\hline \multirow{2}{*}{$\begin{array}{l}\text { Konsentrasi Tepung } \\
\text { Sawo Mentega }\end{array}$} & \multicolumn{3}{|c|}{ Konsentrasi Ester Sukrosa } & \multirow{2}{*}{$\begin{array}{c}\text { Es Krim Tepung Sawo Mentega } \\
\text { dengan Kuning Telur } \\
\text { (Yuliana, 2018) }\end{array}$} \\
\hline & $0,1 \%$ & $0,3 \%$ & $0,5 \%$ & \\
\hline $10 \%$ & $\begin{array}{c}3,84 \\
\text { (suka) }\end{array}$ & $\begin{array}{c}3,50 \\
\text { (suka) }\end{array}$ & $\begin{array}{c}4,00 \\
\text { (suka) }\end{array}$ & $\begin{array}{c}1,91 \\
\text { (agak tidak suka) }\end{array}$ \\
\hline $15 \%$ & $\begin{array}{c}3,17 \\
\text { (biasa) }\end{array}$ & $\begin{array}{c}3,10 \\
\text { (biasa) }\end{array}$ & $\begin{array}{c}3,10 \\
\text { (biasa) }\end{array}$ & $\begin{array}{c}1,98 \\
\text { (agak tidak suka) }\end{array}$ \\
\hline
\end{tabular}

Berdasarkan Tabel 12, skor hedonik tekstur berkisar 3,10-4,00 yang termasuk kategori biasasuka. Es krim tepung sawo mentega memanfaatkan lemak yang terdapat pada buah sawo mentega dan susu yang menyebabkan tekstur yang dihasilkan kurang lembut. Penyerapan air oleh tepung sawo mentega membuat total padatan terlarut dan viskositas meningkat, sehingga mengakibatkan tekstur es krim menjadi lebih padat dan keras. Viskositas yang terlalu tinggi membuat penerimaan es krim dengan penambahan tepung sawo mentega $15 \%$ kurang diminati dibandingkan dengan penambahan tepung sawo mentega $10 \%$. Peran lemak dalam es krim membantu pembentukan tekstur (Ismunandar, 2004). Sedangkan, ester sukrosa memiliki peran dalam meningkatkan pengadukan (Chan, 2008), sehingga lemak dan bahan lainnya tersebar secara merata yang membuat tekstur es krim menjadi lembut secara merata.

Selain itu, pengembangan volume adonan (overrun) es krim menjadikan es krim lebih ringan dan tidak terlalu padat sehingga mempunyai tekstur yang lembut (Haryanti dan Zueni, 2015). Hal ini terlihat dari es krim dengan penambahan tepung buah sawo mentega $10 \%$ dengan penambahan ester sukrosa sebanyak 0,5\% memiliki skor hedonik yaitu 4,00 dengan kategori suka dan memiliki nilai overrun sebesar $93,57 \%$.

\section{KESIMPULAN}

Penambahan ester sukrosa $0,1 \%, 0,3 \%$, dan $0,5 \%$ pada es krim dengan tepung buah sawo mentega $10 \%$ memberikan karakteristik fisik es krim tepung buah sawo mentega adalah $71,43 \%$, $74,10 \%$, dan $93,57 \%$ untuk overrun; $0,250 \mathrm{~cm}, 0,225 \mathrm{~cm}$, dan $0,175 \mathrm{~cm}$ pada pemisahan krim saat uji stabilitas emulsi; 24,31 menit, 26,16 menit, dan 31,00 menit untuk waktu leleh; $14680 \mathrm{cP}, 18620$ CP, dan $12730 \mathrm{cP}$ untuk nilai viskositas; serta $33,47 \%, 33,62 \%$, dan $36,47 \%$ untuk total padatan terlarut. Penambahan ester sukrosa $0,1 \%, 0,3 \%$ dan $0,5 \%$ pada es krim dengan tepung buah sawo mentega $15 \%$ memberikan karakteristik fisik es krim tepung buah sawo mentega adalah $50,00 \%$, $57,14 \%$, dan $64,28 \%$ untuk overrun; $0,250 \mathrm{~cm}, 0,150 \mathrm{~cm}$, dan $0,150 \mathrm{~cm}$ pada pemisahan krim saat uji stabilitas emulsi; 30,02 menit, 33,33 menit, dan 36,13 menit untuk waktu leleh; $16560 \mathrm{cP}, 17020$ CP, dan 17380 cP untuk nilai viskositas; serta $33,62 \%, 34,47 \%$, dan $39,98 \%$ untuk total padatan 
terlarut. Penambahan ester sukrosa pada es krim dengan tepung sawo mentega $10 \%$ menghasilkan penerimaan hedonik suka terhadap warna, tekstur, dan rasa, serta biasa-suka terhadap aroma. Penambahan ester sukrosa pada es krim dengan tepung sawo mentega $15 \%$ menghasilkan penerimaan hedonik suka-sangat suka terhadap warna, biasa terhadap tekstur dan rasa, serta biasasuka terhadap aroma.

\section{DAFTAR PUSTAKA}

Anwar, S.H., Ginting, B.M., Aisyah, Y., dan Safriani, N. (2017). Pemanfaatan Tepung Porang (Amorphophallusoncophyllus) sebagai Pentabil Emulsi M/A dan Bahan Penyalut pada Mikrokapsul Minyak Ikan. Jurnal Teknologi Hasil Pertanian, 27(1), hlm. 76-78.

Arbuckle, Wendell. S. (1986). Ice Cream. Edisi keempat. New York: Springer Science+Business Media New York.

Bodyfelt, F.W., Tobias, J., dan Trout G.M. (1988). The Sensory Evaluation of Dairy Product. New York: Van Nostrand Reinhold.

Chan, L.A. (2008). Membuat Es Krim. Jakarta: PT. Agromedia Pustaka.

Clarke, Chris. (2012). The Science of Ice Cream. Edisi kedua. Cambridge: The Royal Society of Chemistry.

Ermawati, W.O., Wahyuni, S., dan Rejeki, S. (2016). Kajian Pemanfaatan Limbah Kulit Pisang Raja (Musa paradisiaca var Raja) dalam Pembuatan Es Krim. Jurnal Sains dan Teknologi Pangan, 1(1), hlm. 67-72.

Filiyanti, I., Affandi, D.R., dan Amanto, B.S. (2013). Kajian Penggunaan Susu Tempe dan Ubi Jalar Ungu Sebagai Pengganti Susu Skim pada Pembuatan Es Krim Nabati Berbahan Dasar Santan Kelapa. Jurnal Teknosains Pangan, 2(2), hlm. 57-65.

Frandsen, J.H., dan Aebuckle W.S. (1961). Ice Cream and Related Product. Connecticut: The Avi Publishing Company.

Friberg, S., Larsson, K., dan Sjoblom, J. (2005). Food Emulsions. Edisi keempat. New York: Marcel Dekker.

Haryanti, N. dan Zueni, A. (2015). Identifikasi Mutu Fisik, Kimia dan Organoleptik Es Krim Daging Kulit Manggis (Garcinia mangostana L.) dengan Variasi Susu Krim. Jurnal Agritepa, 1(2), hlm. 143-156.

Ismunandar. (2004). Dibalik Lembutnya Es Krim. [Online]. Diakses dari http://www.kimianet.lipi.go.id/utama.cgi?cetakartikel\&1102121768.

Iteh, Ruth Melina. (2012). Penggunaan Ester Sukrosa atau Mono/Di-gliserida Dibandingkan dengan Kuning Telur dalam Memperbaiki Beberapa Karakteristik Fisik Es Krim. (Skripsi). Fakultas Teknologi Pertanian, Universitas Katolik Soegijapranata, Semarang.

Khoirunnisa N.F.F. (2016). Kajian Fisikokimia Tepung Sawo Mentega (Pouteria campechiana) dengan Variasi Suhu Pengeringan. Riset Agroindustri. UPI Bandung.

Nurjaya dan Maulida, N. (2018). Tingkat Kesukaan Konsumen Pada Atribut Beras Pandanwangi Murni Cianjur. Jurnal Agroscience, 8(1).

McGee. (2004). On Food and Cooking: The Science and Lore of the Kitchen. New York: Scribner.

Mitsubishi-Chemical Food. (2019). Sucrose Fatty Acid Ester: Ryoto ${ }^{T M}$ Sugar Ester. [Online]. Diakses dari https://www.m-chemical.co.jp/en/products/departments/group/mfc/product 11201443_7739.html.

Muchtadi, T.R., Sugiyono., dan Ayustaningwarno, F. (2015). IImu Pengetahuan Bahan Pangan. Bandung: Alfabeta.

Muse, M.R., dan Hartel, R.W. (2004). Ice Cream Structural Elements that Affect Melting Rate and Hardness. Journal of Dairy Science, 87, hlm. 1-10.

Rauf, R., dan Sarbini, D. (2015). Daya Serap Air sebagai Acuan untuk Menentukan Volume Air dalam Pembuatan Adonan Roti dari Campuran Tepung Terigu dan Tepung Singkong. Jurnal Agritech, 35(3), hlm. 324-330. 
Sakawulan, D., Budi, F.S., dan Syamsir, E. (2014). Pembuatan Velva Fruit Pisang dengan Bahan Dasar Tepung Pisang dan Carboxy Methyl Cellulose sebagai Bahan Penstabil. Jurnal Indonesian Food Technologists, 3(4), hlm. 182-187.

Standar Nasionaol Indonesia. (1995). SNI 01-3713-1995: Es krim. Jakarta: Badan Standardisasi Nasional.

Standar Nasional Indonesia. (2009). SNI 3751:2009: Tepung Terigu Sebagai Bahan Makanan. Jakarta: Badan Standarisasi Nasional.

Sunila, A.V. dan Murugan, K. (2017). Nutritional Composition of Fruits from Pouteria Campechiana (Kunth) Baehani at Different Stages of Development, Jurnal Bioscience, 10(20), hlm. 40204026.

Szüts, A. dan Szabó-Révész, P. (2012). Sucrose Esters as Natural Surfactants in Drug Delivery Systems-A Mini-Review. International Journal of Pharmaceutics 433, hlm. 1-9.

Whitehurst, R.J. (2004). Emulsifiers in Food Technology. New Jersey: Blackwell Publishing.

Yuliana, S. (2018). Formulasi Es Krim Tepung Buah Campoleh (Pouteria campechiana). Laporan Riset Agroindustri. Program Studi Pendidikan Teknologi Agroindsutri. Universitas Pendidikan Indonesia. Bandung.

Zahro, C. dan Nisa, F.C. (2015). Pengaruh Penambahan Sari Anggur (Vitis vinifera L.) dan Penstabil terhadap Karakteristik Fisik, Kimia dan Organoleptik Es Krim. Jurnal Pangan dan Agroindustri, 3(4), hlm. 1481-1491. 